\title{
Effect of Extraction Treatment on MOR and MOE Binder Less Particle Board From Coconut Fiber
}

\author{
Erna Yusniyanti ${ }^{1}$, Milawarni $^{2}$ and Nurlaili ${ }^{3}$ \\ \{erna_yusniyanti@yahoo.com\} \\ ${ }^{1}$ Civil Engineering, Politeknik Negeri Lhokseumawe, , Lhokseumawe, Indonesia \\ ${ }^{2}$ Electrical Engineering, Politeknik Negeri Lhokseumawe, Lhokseumawe, Indonesia \\ ${ }^{3}$ Mechanical Engineering, Politeknik Negeri Lhokseumawe, Lhokseumawe, Indonesia
}

\begin{abstract}
This research is to develop environmentally friendly particle board and technology and products, both in terms of raw materials and also process technology and products that will be produced. In terms of raw materials, coconut fiber is used from smallholder estates, while in terms of technology and products, we have developed a technology for making binder less particle board. The physical and mechanical properties in particular the MOR and MOE values of the binder less particle board are strongly influenced by the preliminary treatment and forged time. The effect of preliminary treatment of raw materials from binder less particle board coconut fibber can be known by calculating the MOR and MOE values on the particle board. This research is to find the right way of making particle board without adhesive by doing the extraction process. Methods used are methods without treatment, boiling, steaming and immersion. Characterization includes density, water absorption, thickness, MOR and MOE. The results of this study indicate that steam extraction treatment can increase the MOR and MOE values along with the addition of 10- to 15-minute welding time of $70 \mathrm{kgf} / \mathrm{cm}^{2}$ to $79 \mathrm{kgf} / \mathrm{cm}^{2}$ and MOE value of $18,000-19,300 \mathrm{kgf} / \mathrm{cm}^{2}$.
\end{abstract}

Keywords: Particle board, Coconut Fiber, MOE, MOR

\section{INTRODUCTION}

Indonesia is an agricultural country where most of the population is farmers. One of them is traditional farmers engaged in the field of coconut plantation. Processing of coconut waste especially coconut husk for household use not maximal utilization. So far, the use of coconut fiber is only used for doormat, brush, broom and others.

Industries engaged in the management of timber forest products have constraints in meeting the supply of raw materials. Because it is developed composite products that are environmentally friendly and able to become alternative wood raw materials so as to increase the added value and profit. Particle board is one kind of composite board product developed to improve the efficiency of the utilization of wood and non timber raw materials, as well as lignocelluloses and hemicelluloses materials [1].

Meanwhile, in terms of environmental aspects, particle board technology currently used still has a number of problems, especially those related to the use of adhesives. Since most 
adhesives are used formaldehyde-based [2], [3], the particle board product has the potential to generate formaldehyde emissions during its use. Formaldehyde compounds can cause cancer, irritation of the eyes and oesophagus and the occurrence of respiratory distress [4]. Thus in terms of the basic ingredients of manufacture and adhesives used are not friendly to the environment.

Attempts to find new, more environmentally friendly products are, among others, by developing adhesives using renewable feedstock's, such as lignin and tannin [5]. Methods that have been developed include steam injection method, enzymatic treatment, and wood surface oxidation method. The preliminary treatment through steam to the kenaf core can improve the mechanical properties of particle-free MOE particles [6].

Natural fiber lignocelluloses derived from non-wood fiber there are abundant one of which by-product of coconut plantation is coconut husk. Considering the benefits of very slim coconut fiber to be developed, it will be interesting to do some research, how to make coconut coir more useful, one of them is the use of particle board which is then used for household or industrial needs [7].

Coconut fiber has a chemical component that is almost the same as the elements of the constituent elements of wood. Coconut fiber is a lignin material that contains lignin $29.23 \%$ [8], thus can be utilized for particle board feedstock, through his research on binder less particle board of coconut fiber with pre-treatment through boiling invisible can increase the value of MOE. [4] states that in the process of making the particle board it is shown that the pre-treatment either extracted by heating or cooling on the particle can improve the properties of the board.

Research on the manufacture of binder less particle board from bamboo and sengon wood by oxidation method and boiling treatment is done [9]. The results showed that particle boards using formaldehyde adhesives had lower stability and mechanical properties than the binder less particle board.

The development of particle board by using steam heat injection was developed intensively by [10]. The results of [11] shows that in making binder less particle board of kenaf cores with the use of heat steam injection method obtained particle board with a very high stickiness value that is at board density of $0.65 \mathrm{gcm}^{-3}$ or more.

The business of making binder less particle board is also developed by another method that is through oxidation of particles or wood fibers by using hydrogen peroxide and catalyst. Compared with the enzymatic treatment and heat-up injection system, research with this method appears not to be intensively conducted. Research production of binder less particle board from Castor Cake Meal has been successfully performed by [12] through variations of pressure and temperature of felts able to improve the physical properties of binder less particle board. The preliminary treatment of binder less particle board from OPEFB can improve its physical properties [13].

The quality of binder less particle board can be influenced by several factors such as extractive removal treatment and wick time used. [6] in his research stated that the modulus value of fracture increased on particle board by using the waste material of sawdust mahogany after boiling treatment. The results showed that the mechanical properties of the particle board increased in high density and the cultivar saqie and the particle surface were smooth. [14].

The target of this research is to get a product that can be applied in the development of bio composite technology. The following table 1. Are JIS A 5905: 2003 and 2006 testing of physical and mechanical properties of particle board. 
Table 1. Testing standards for physical and mechanical properties of particle board

\begin{tabular}{cccc}
\hline No & Physical and Mechanical Properties & JIS A 5905:2003 & SNI 03-2105-2006 \\
\hline 1 & Density & $0.40-0.90 \mathrm{~g} / \mathrm{cm}^{3}$ & $0.40-0.90 \mathrm{~g} / \mathrm{cm}^{3}$ \\
2 & Water content & $5-13 \%$ & Maximum $14 \%$ \\
3 & thickness & Maximum $12 \%$ & Maximum $12 \%$ \\
4 & firmness broken & Minimum $20000 \mathrm{kgf} / \mathrm{cm}^{2}$ & Minimum $20400 \mathrm{kgf} / \mathrm{cm}^{2}$ \\
5 & MOR & Minimum $80 \mathrm{kgf} / \mathrm{cm}^{2}$ & Minimum $82 \mathrm{kgf} / \mathrm{cm}^{2}$ \\
6 & MOE & Minimum $30 \mathrm{kgf} / \mathrm{cm}^{2}$ & Minimum $31 \mathrm{kgf} / \mathrm{cm}^{2}$
\end{tabular}

The physical and mechanical strength of the particle board is strongly influenced by its chemical structure. Table 2 below is a chemical composition of coconut fiber.

Table 2. Chemical Composition of coconut fiber

\begin{tabular}{llcc}
\hline No & Component & Coir $(\%)$ & $\begin{array}{c}\text { Coir fiber } \\
(\%)\end{array}$ \\
\hline 1 & Water & 26.00 & 5.25 \\
2 & Pectin & 14.25 & 3.00 \\
3 & Hemicellulose & 8.50 & 0.25 \\
4 & Lignin & 29.23 & 45.84 \\
5 & Cellulose & 21.07 & 43.44 \\
\hline
\end{tabular}

\section{METHODS}

Metedology used with the selection of tools and materials and work procedures as follows

\subsection{Tools and Materials}

This study included into the type of experimental research in the laboratory. This study uses several tools, among others, test equipment: Bending Equipment-MOE and MOR (Type: SC-2 DE, cap. $2000 \mathrm{kgf}$ ) and Hot Press. Measuring instruments: Digital scales, measuring cups, rulers, clocks. Dryer: oven. K3 tools: gloves and masks. Tools: particle filter, steamer, stove, gas, mold, aluminium foil, stirrer, spoon. Cleaner: lap. The research material is coconut fiber.

\subsection{Measurement}

This research is done through the stage of material preparation, extraction process, sample printing and sample testing as shown 1. below.

The following is a picture 1 for his research procedure. 


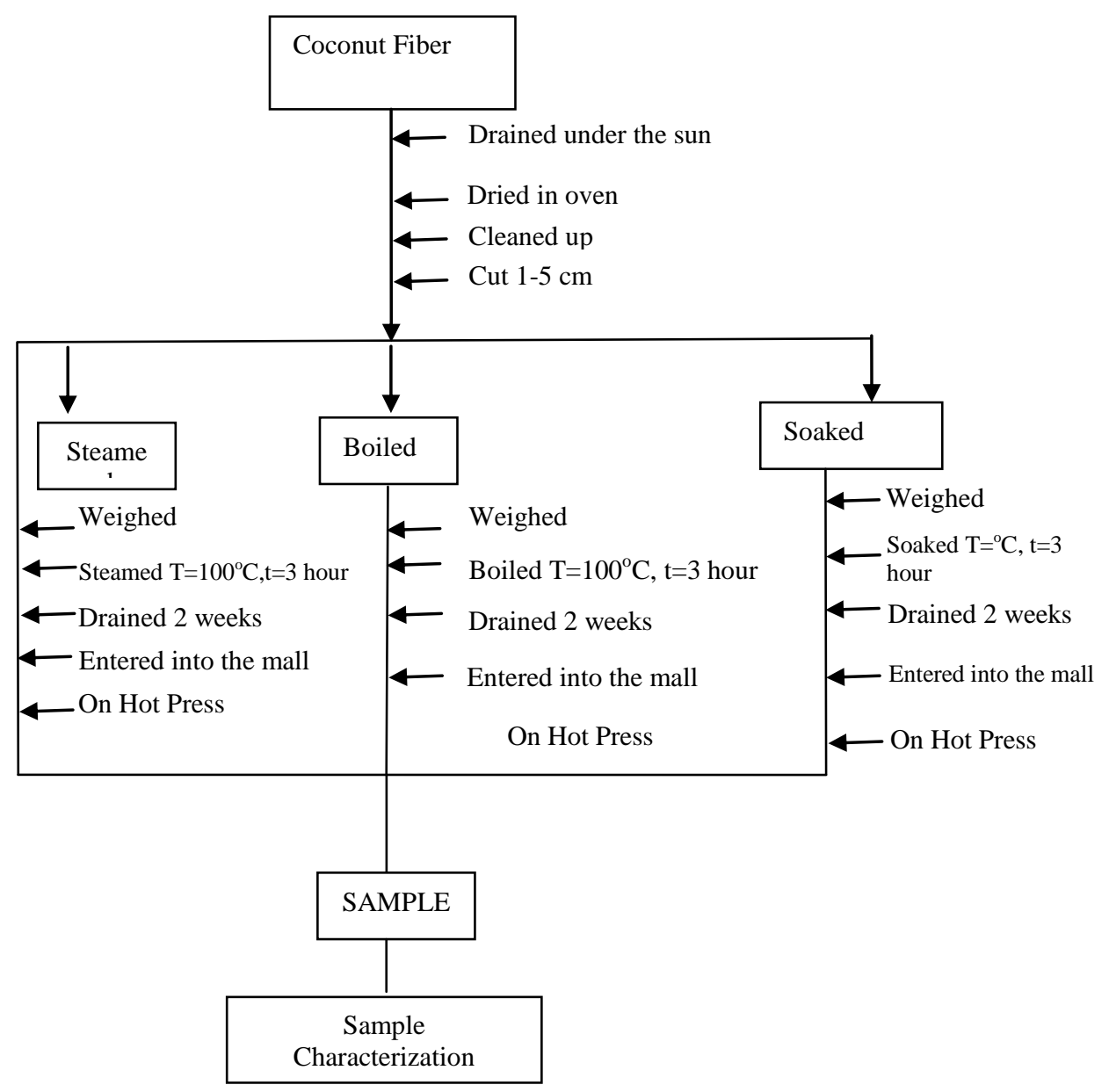

Fig. 1 Research flow diagram

\subsection{Particle board Characteristics}

\subsubsection{Density}

To know the physical properties of the particle board, density testing ( $\rho$ ), water absorption (KA) and thickness (PT) are as follows: Density $(\rho)$. The density test was carried out in dry conditions, and then the sample weighed the weight and measured the average length, width and thickness to determine the volume value. The formula used is:

$$
\rho=\frac{\mathrm{m}}{\mathrm{V}}
$$

Where:

$\rho=$ density $\left(\mathrm{g} / \mathrm{cm}^{3}\right)$

$\mathrm{m}=$ density $(\mathrm{g})$

$\mathrm{v}=$ volume $\left(\mathrm{cm}^{3}\right)$ 


\subsubsection{Water Absorption (KA)}

Water absorption is calculated by the formula:

$$
\mathrm{KA}=\frac{\mathrm{m} 1-\mathrm{m} 2}{\mathrm{~m} 2} \times 100 \%
$$

Where:

$\mathrm{KA}=$ water absorption $(\%)$

$\mathrm{M}_{1}=$ sample weight before immersion

$\mathrm{M}_{2}=$ sample weight after immersion

\subsubsection{Thickness}

Calculated by the formula:

$$
\mathrm{PT}=\frac{\mathrm{T} 2-\mathrm{T} 1}{\mathrm{~T} 1} \mathrm{x} 100 \%
$$

\subsubsection{Testing of Mechanical Properties}

Strong bending testing is done with Universal Testing Machine.

\section{a. Modulus of Repture (MOR)}

Calculated by the formula:

$$
\sigma=\frac{3 \mathrm{PL}}{2 \mathrm{bd}^{2}}
$$

Where:

$\sigma=$ strong bending $\left(\mathrm{kgf} / \mathrm{cm}^{2}\right)$

$\mathrm{P}=$ Maximum load weight $(\mathrm{kgf})$

$\mathrm{L}=$ distance of buffer $(\mathrm{cm})$

$\mathrm{b}=$ width of test sample $(\mathrm{cm})$

Thick test sample $(\mathrm{cm})$

\section{b. Modulus of Elasticity (MOE)}

Strong bending test (Modulus of Elasticity), using the formula:

$$
\mathrm{MOE}=\frac{\Delta \mathrm{PL}^{3}}{4 \Delta \mathrm{Ybd}^{3}}
$$

Where:

MOE $=$ Modulus of Elasticity $\left(\mathrm{kgf} / \mathrm{cm}^{2}\right)$

$\mathrm{P}=$ load (kgf)

$\mathrm{L}=$ distance of buffer

$\mathrm{b}=$ sample width $(\mathrm{cm})$

$\mathrm{d}=$ sample thickness $(\mathrm{cm})$

$\Delta \mathrm{Y}=$ flexibility in load $(\mathrm{cm})$ 


\section{RESULTS}

Density test results, water absorption and thickness test. Density or density of the masses is the ratio of mass to the volume or the amount of mass of matter per unit volume. Density is one of physical properties very influential on the quality of particle board. The density is directly related to the porosity, is the proportion of the empty cavity volume, the higher the board density the higher the stiffness and strength. Data from particle board density testing were calculated using equation 2.1. Here is a table of test results and calculation of the average density value.

Table 3. Density values, water absorption and thickness of the particle board

\begin{tabular}{|c|c|c|c|c|c|c|c|c|c|c|}
\hline \multirow{4}{*}{ Parameter Test } & \multicolumn{10}{|c|}{ Treatment } \\
\hline & \multicolumn{2}{|c|}{$\begin{array}{l}\text { Without } \\
\text { Treatment }\end{array}$} & \multicolumn{2}{|c|}{ Boiling } & \multicolumn{2}{|c|}{$\begin{array}{l}\text { Steamin } \\
\mathrm{g}\end{array}$} & Immersion & \multicolumn{3}{|c|}{$\begin{array}{l}\text { Without Treatme } \\
\text { + Starch }\end{array}$} \\
\hline & \multicolumn{10}{|c|}{ Duration of Forging (minute) } \\
\hline & 10 & 15 & 10 & 15 & 10 & 15 & 10 & 15 & 10 & 15 \\
\hline $\begin{array}{l}\text { Density Average } \\
\qquad\left(\mathrm{g} / \mathrm{cm}^{3}\right)\end{array}$ & 0,604 & 0,68 & 0,59 & 0,56 & 0,69 & 0,724 & 0,559 & 0,69 & 0,60 & 0,62 \\
\hline $\begin{array}{l}\text { Average water } \\
\text { absorption }(\%)\end{array}$ & 7,50 & 6,6 & 7,72 & 6,3 & 5,11 & 4,20 & 7,60 & 6,92 & 6,20 & 6,00 \\
\hline $\begin{array}{c}\text { Average Thickness } \\
(\%)\end{array}$ & 13,26 & 12,7 & 13,3 & 12,4 & 11,0 & 10,08 & 12,69 & 11,9 & 11,4 & 10,69 \\
\hline
\end{tabular}

\section{Test Results MOR and MOE}

The result of testing of mechanical properties on binder less particle board from this research is done by MOR and MOE test. The MOR and MOE test values of binder less particle board of coconut fiber are shown in table 4 below :

Table 4. MOR and MOE values of binder less particle board of coconut fiber.

\begin{tabular}{|c|c|c|c|c|c|c|c|c|c|c|}
\hline \multirow{4}{*}{$\begin{array}{l}\text { Parameter } \\
\text { Test }\end{array}$} & \multicolumn{10}{|c|}{ Treatment } \\
\hline & \multicolumn{2}{|c|}{$\begin{array}{l}\text { Without } \\
\text { Treatment }\end{array}$} & \multicolumn{2}{|c|}{ Boiling } & \multicolumn{2}{|c|}{ Steaming } & \multicolumn{2}{|c|}{ Immersion } & \multicolumn{2}{|c|}{$\begin{array}{c}\text { Without } \\
\text { Treatment }+ \text { Starc }\end{array}$} \\
\hline & \multicolumn{10}{|c|}{ Duration of Forging (minute) } \\
\hline & 10 & 15 & 10 & 15 & 10 & 15 & 10 & 15 & 10 & 15 \\
\hline $\begin{array}{l}\mathrm{MOR} \\
\left(\mathrm{kgf} / \mathrm{cm}^{2}\right)\end{array}$ & 60 & 63 & 62 & 67 & 70 & 79 & 60 & 64 & 59 & 62 \\
\hline $\begin{array}{l}\mathrm{MOE} \\
\left(\mathrm{kgf} / \mathrm{cm}^{2}\right)\end{array}$ & 12.800 & 13.000 & 13.000 & 14.500 & 18.000 & 19.300 & 11.800 & 12000 & 12.000 & 12.500 \\
\hline
\end{tabular}




\section{DISCUSSION}

From the research that has been done then obtained data test results. From this data can be calculated physical properties such as density, moisture content, thickness development and mechanical properties such as flexural strength (MOR) and strength elasticity (MOE).

\subsection{Physical Characteristics of Particle board}

The value of the obtained density is lower than the expected target density. The expected density is $0.75 \mathrm{~g} / \mathrm{cm}^{3}$, whereas the density is 0.559 to $0.724 \mathrm{~g} / \mathrm{cm}^{3}$. Although the density presented did not match the target, the density still met the JIS standard, Is particle board density $0.40-0.90 \mathrm{~g} / \mathrm{cm}^{3}$. Here is figure 2 Effect of extraction treatment on binder less particle board coconut fiber.

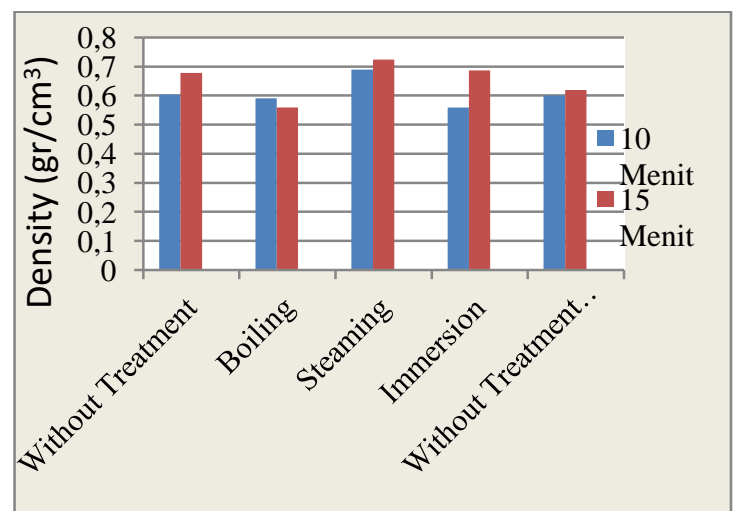

Fig. 2 Effect of extraction treatment on particle board density values of coconut fiber.

Coconut fibers that experience the process of boiling extraction show darker fiber colour and size becomes more subtle, than before. However, coconut fiber after the steaming process tends to be brighter. While the immersion process is darker than the steaming process but brighter than the boiling process. This indicates that the extractive content of coconut fiber is dissolved during the boiling process more than the steaming and soaking process. In addition, a relatively long boiling time of 3 hours and direct contact between the particles and boiling water makes the fiber becomes smoother and slightly crushed.

The time factor of the forging has a significant effect on the density of particle board without adhesive, which increases in value with the increase of felting time. Similar results are also demonstrated by [4], [10], where particle board density increases with increasing heat for 7 to 20 minutes on mahogany particles and kenaf core. The steaming treatment can increase the density value at the time of forging 10 to 15 minutes. The density value obtained in this steaming process is $0.690-0.700 \mathrm{~g} / \mathrm{cm}^{3}$. Longer quenching time provides an opportunity for particles to contact each other well and more compressed.

The moisture value of the test results and the calculation of an binder less particles of coconut fiber after 7 days of conditioning ranged from $5.11 \%$ to $7.70 \%$, this can be seen in Figure 3 which already meets the required particle water particle moisture by [15] standard is $5 \%-13 \%$. 


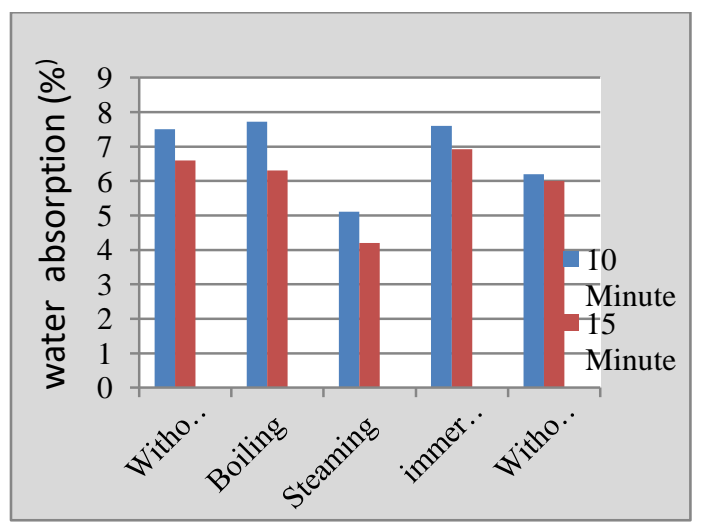

Fig. 3 The effect of the extraction treatment on the water absorption on the particle board .

Based on the picture of 3 samples on the steaming treatment has decreased the value of water absorption when compared with the sample without treatment and samples using starch has increased the value of water content. This is because in the manufacture of particle board using starch flour with a mixture of water. The moisture value of boards is more influenced by the internal structure of the board than the nature of the bonding board [16] The relatively short averaging time is about 10-15 minutes, the extraction treatment can decrease the water absorption of the board. The value of particle board thickness development in this study ranged between $10.68 \%-13.32 \%$. While the maximum standard $12 \%$ [15] . Furthermore, the effect of coconut fiber extraction treatment on the thickness development test of the particle board is shown in Figure 4.

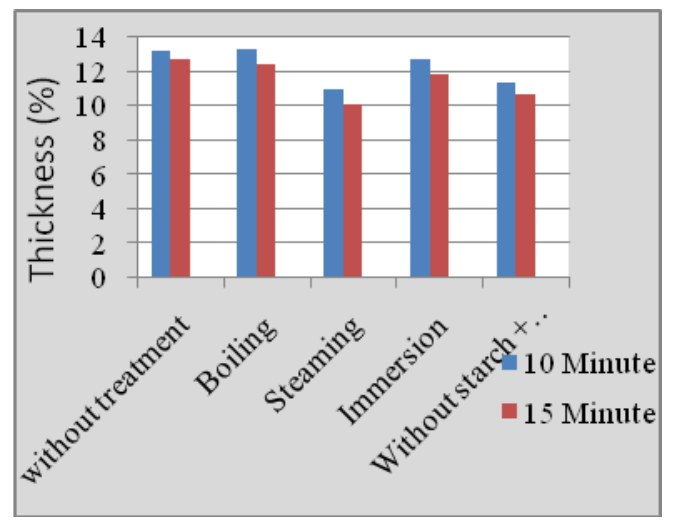

Fig. 4 The effect of the extraction treatment on the thickness of the binder less particle board coconut fiber

\subsection{Mechanical Characteristics of Particle Board}

The MOR (Modulus of Rupture) and MOE (Modulus of Elasticity) tests are used to look at the mechanical properties of the particles. The fracture modulus (MOR) value of particle board experiments in this study ranged from $59 \mathrm{kgf} / \mathrm{cm}^{2}-79 \mathrm{kgf} / \mathrm{cm}^{2}$. Figure 5 Effect of extraction treatment on MOR values. 


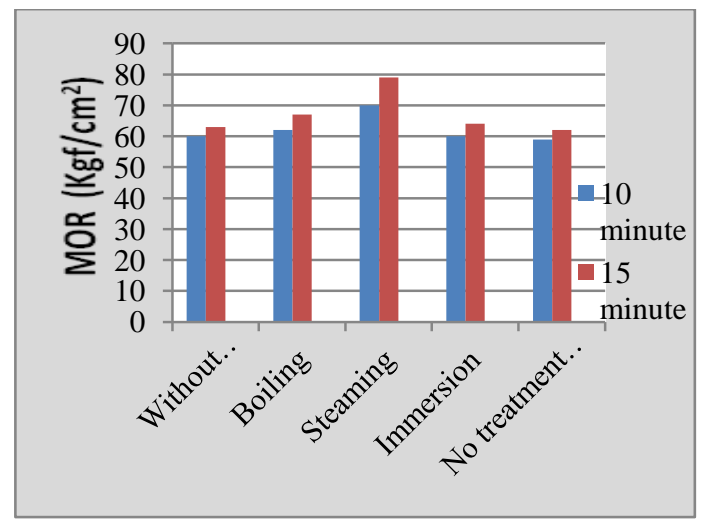

Fig. 5 Effect of preliminary treatment (extraction) on MOR values

Based on figure 5 it is known that the extraction treatment showed a significant effect on the value of the MOR. The extraction treatment by steaming on the coconut fiber provides a higher fracture modulus value compared with boiling and immersion or without treatment. Over time forging can decrease the value of the broken modulus. In boiling treatment, it is suspected that there is a significant chemical degradation process, especially at long enough forging time, thereby decreasing the value of the broken modulus (MOR).

It is also supported by darker-colored fibers after the boiling process. There are many possible chemical reactions that take place. These chemical reactions can be summarized as follows: degradation of hemicelluloses and cellulose that form simple sugars and other decompositions, thermal degradation of cell wall matrix, bond formation between carbohydrate and lignin polymers and increased cellulose crystallization. According to research [17], steaming treatment on EFB may increase the MOR value of the boiling treatment.

The following illustrates 6. Effect of the extraction treatment on MOE strength of binder less particle board of coconut fiber.

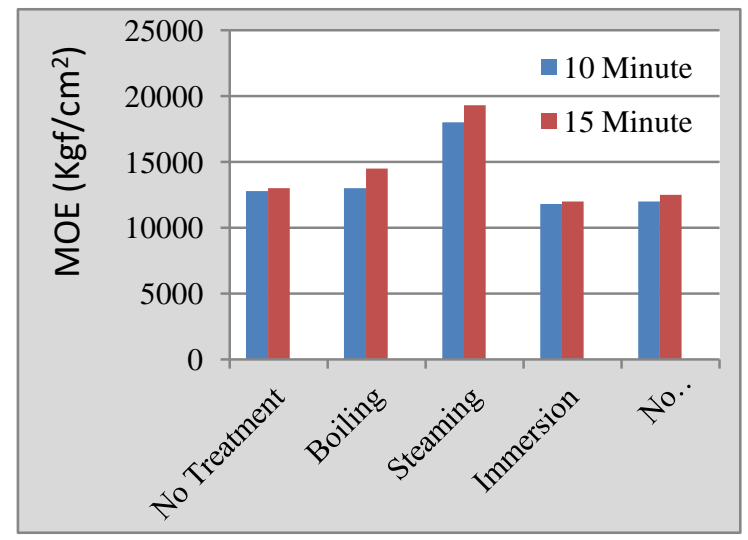

Fig. 6 Effect of extraction treatment on MOE value 
Test results and calculations show that the elasticity modulus value of gluten free particle board (MOE) of this coconut fiber shows that the effect of the extraction treatment and the timing of the impacts on the MOE value. In this steaming process, the value of MOE increases with the increase of felting time.[18] in his research obtained some increase in MOE values from particle board from elephant grass along with increased wax time from 5 to 14 minutes. It is assumed that the longer the heat forging will be the greater the thermoplastic component in the coconut fiber so that will increase the MOE. Plasticity may be derived from thermoplastic extractive substances which will soften during heat treatment. On the other hand, a boiling extraction process followed by a 15 minute long forged time indicates the lowest MOE value. It is assumed that the boiling process occurs degradation chemical components in the fiber cause damage to the fiber so that the effect on the low value of MOE.

\section{CONCLUSIONS}

Based on the results of the analysis and discussion of this study can be drawn some conclusions as follows:

1. The interaction between the extraction treatment and the time of the fitting effect on the physical properties of particle board without adhesive, the average density ranges from $0,559-0,724 \mathrm{~kg} / \mathrm{cm}^{3}$, average water absorption $4,20-7,72 \%$ and mean of thickness of 10.08 $-13.32 \%$.

2. The treatment of extraction and time of impact affect the properties of elasticity modulus (MOE) and fracture strength (MOR) particle board, MOE average value 18000-19.300 $\mathrm{kgf} / \mathrm{cm}^{2}$, while the MOR value is $70 \mathrm{kgf} / \mathrm{cm}^{2}$ to $79 \mathrm{kgf} / \mathrm{cm}^{2}$

3. The steaming extraction treatment has the best physical and mechanical properties in accordance with JIS A 5905; 2003 standard.

\section{ACKNOWLEDGEMENTS}

I would like to thank the director, the head of the civil engineering department and the $\mathrm{P} 2 \mathrm{~m}$ PNL unit who has provided assistance for the implementation of this research

\section{REFERENCES}

[1] R. Widyorini, J. Xu, K. Umemura, and S. Kawai, "Manufacture and properties of binderless particleboard from bagasse I: Effects of raw material type, storage methods, and manufacturing process," J. Wood Sci., vol. 51, no. 6, pp. 648-654, 2005.

[2] P. S. H'ng, S. H. Lee, Y. W. Loh, W. C. Lum, and B. H. Tan, "Production of low formaldehyde emission particleboard by using new formulated formaldehyde based resin," Asian Journal of Scientific Research, vol. 4, no. 3. pp. 264-270, 2011.

[3] J. Z. Zhang, J. Z. Li, and S. F. Zhang, "Properties of Particleboard Manufactured with Modified Urea-Formaldehyde Resin,” Adv. Mater. Res., vol. 150-151, pp. 1135-1138, 2010.

[4] R. Hashim et al., "Effect of particle geometry on the properties of binderless 
particleboard manufactured from oil palm trunk," Mater. Des., vol. 31, no. 9, pp. 4251-4257, 2010.

[5] A. Santoso, "PemanfaatanLignin dan Tanin Sebagai Alternatif Substitusi Bahan Perekat Kayu Komposit," 2013.

[6] R. Widyorini et al., "Improving the Physico-Mechanical Properties of Eco-Friendly Composite Made from Bamboo," Adv. Mater. Res., vol. 896, pp. 562-565, 2014.

[7] Y. Sudarsono, R, Toto, S, "Pembuatan Papan Partikel Berbahan Baku Sabut Kelapa," J. Teknol., vol. 3, no. 1, pp. 22-32, 2010.

[8] K. Syamsu, R. Pespitasari, and H. Roliadi, "Penggunaan Selulosa Mikrobial Dari Nata De Cassava Dan Sabut Kelapa Sebagai Pensubstitusi Selulosa Kayu Dalam Pembuatan," ... -jurnal Agro-Industri Indones., vol. 1, no. 2, pp. 118-125, 2012.

[9] M. Y. Massijaya, Y. S. Hadi, and A. Santoso, "Particle Oxidation Time for the Manufacture of Binderless Particleboard."

[10] J. Xu, R. Widyorini, and S. Kawai, "Properties of kenaf core binderless particleboard reinforced with kenaf bast fiber-woven sheets," J. Wood Sci., vol. 51, no. 4, pp. 415420, 2005.

[11] R. Widyorini, "Pengaruh Metode Pengempaan dan Ukuran Partikel terhadap Sifat Fisik Mekanik Binderlessboard dari Kenaf Inti ( Effect of Pressing Method and Particle Size on Physical-Mechanical Properties of Binderlessboard from Kenaf Core )," pp. 340-345, 2009.

[12] I. A. Kartika, "PRODUCTION OF BINDERLESS PARTICLEBOARD FROM CASTOR CAKE MEAL," vol. 4, no. 1, 2015.

[13] Ratri Yuli Lestari, "Properties Of Binderless Particleboards From Oil Palm Empty Fruit Bunch," Widyariset, vol. 16, no. 2, pp. 219-226, 2013.

[14] S. Hegazy and K. Ahmed, "Effect of Date Palm Cultivar, Particle Size, Panel Density and Hot Water Extraction on Particleboards Manufactured from Date Palm Fronds," Agriculture, vol. 5, no. 2, pp. 267-285, 2015.

[15] JIS A 5908, Japanese Industrial for Particleboard. Jepang, 2003.

[16] nobuhisa okuda M, "Manufacture and mechanical properties of binderless boards from kenaf core," no. April 2002, pp. 53-54, 2004.

[17] T. Sucipto, "Karakterisasi Partikel dan Likuida Tandan Kosong Sawit," no. Maloney 1993, 2006.

[18] J. Salvadó, J. A. Velásquez, and F. Ferrando, "Binderless fiberboard from steam exploded Miscanthus Sinensis: Optimization of pressing and pretreatment conditions," Wood Sci. Technol., vol. 37, no. 3-4, pp. 279-286, 2003. 